DOI: http://dx.doi.org/10.12775/ths.2018.003

Gerda Mazlaveckienè

Education Academy of Vytautas Magnus University

gerda.mazlaveckiene@vdu.It

\title{
Assessment of University Students' English Grammar Proficiency in terms of CEFR Criterial Achievement Levels: the Case of Lithuanian University of Educational Sciences
}

\begin{abstract}
Alignment of language teaching and learning with the CEFR is a complicated process. One of the steps in this process is the analysis and evaluation of student performances characteristic of one or another achievement level (Council of Europe, 2018). The current paper focuses on the exploration of university students' English grammar proficiency in terms of CEFR proficiency levels. However, CEFR levels are underspecified with respect to key properties that are tested and assessed by FL teachers and examiners when they assign a learner a particular proficiency level. Therefore, the Cambridge English Profile Programme is employed for a more detailed analysis, as it outlines criterial features for all CEFR proficiency levels. Hence, the present study aims at investigating to what extent the list of grammatical criterial features proposed by the English Profile Programme (EPP) at the University of Cambridge is applicable to students of English Philology in their final year of BA studies when defining their proficiency level according to the CEFR. The findings of the study suggest that Lithuanian students of English Philology tend to make do with a restricted repertoire of grammatical structures which mainly range from level B1 to B2. The author of the paper does not wish to extend the obtained results to the national scale, yet strongly believes that the findings might shed light on and reveal major tendencies in the development of foreign language proficiency of English Philology students in Lithuania.
\end{abstract}


Keywords: Common European Framework of Reference for Languages (CEFR); English Profile Programme (EPP); English Grammar Profile (EGP); grammar proficiency; grammatical criterial features (GCFs); learner corpus; Lithuanian students of English Philology.

\section{Introduction}

Learner corpora have proved to be useful in providing consistent and systematic empirical data for the identification and assessment of learners' competence and proficiency in a foreign language. Through the investigation of actual language use in learner corpora, it is easier for researchers to "understand how best to help students develop competence in the kinds of language they will encounter on a regular basis" (Biber \& Reppen, 1998, p. 157). Moreover, learner corpora also reveal the learning needs of learners and inform language teachers about their students' proficiency in FL. For this reason, learner corpora are becoming an important asset for second language acquisition (Granger, 2002) as well as learning and assessment.

Therefore, the CommonEuropean Framework of Reference forLanguages (Council of Europe, 2018) has become the key document in language teaching, learning and assessment, which has not lost its influence since its first publication in 2001. The CEFR continues to gain wide recognition among language educationalists, education policy makers as well as language teachers and learners not only in Europe but also in other continents (Hulstijn, 2014). It is best known for its six, or rather seven (including pre-A1), levels of language proficiency, each being specified in general illustrative 'can-do' descriptors. According to Juknevičienè and Šeškauskienè (2014), CEFR level descriptors are deliberately formulated in general statements to "allow for a broader application to a variety of contexts" and aim at "the localisation and adaptation of the common descriptors to specific uses" (2014, p. 88). Hence, the CEFR has been translated into 40 languages (Council of Europe, 2018), including Lithuanian, and serves as a basis for national FL curricula development.

The six CEFR levels and their illustrative descriptors have had a major impact on language teaching and assessment practices, especially on the teaching, learning and assessment of foreign languages. As Hawkins and Buttery (2010) claim, these descriptors are formulated in functional terms, i.e. "they describe the different uses to which language can be put and the various functions that learners can perform as they gradually master a second language (L2)" (2010, p. 2). It is noteworthy that the descriptors do not provide 
language-specific details about lexis and grammar that are characteristic to each level of language proficiency. Consequently, some authors claim that CEFR levels are underspecified with respect to key linguistic features that are expected to be acquired by language learners as well as tested and assessed by language teachers (Hawkins \& Buttery, 2010; Callies \& Zaytseva, 2013; Milanovic, 2009; O'Keeffe \& Mark, 2017; Salamoura \& Saville, 2010; and others). For this reason, a number of projects have been implemented with an attempt to align national language curricula with the six CEFR levels of proficiency.

The first attempt to use a learner corpus for the specification of the CEFR proficiency levels was undertaken by the Cambridge English Profile Programme. It is a collaborative programme initiated by the Cambridge ESOL group of Cambridge Assessment, which is directly involved in the development and administration of a number of tests of English as a foreign language (EFL) (Juknevičienė \& Šeškauskienė, 2014). The English Profile Programme (EPP) aims at relating CEFR descriptors to learner corpus evidence as well as seeks "to produce Reference Level Descriptions for English linked to the general principles and approaches of CEFR" (UCLES/ CUP, 2011, p. 2) and "to add grammatical and lexical details of English to CEFR's functional characterisation of the different levels" (Hawkins \& Filipović, 2012, p. 5). Hence, the main focus of EPP is to identify the criterial features for L2 at each CEFR level.

Criterial features are defined as "certain linguistic properties that are characteristic and indicative of L2 proficiency at each level" (Hawkins \& Buttery, 2010, p. 2) and thus can serve as "a basis for estimation of a learner's proficiency level" (Salamoura \& Saville, 2010, p. 102). Four types of criterial features are determined: acquired/learnt language features; developing language features; acquired/native-like usage distributions of a correct feature; and developing/non-native-like usage distributions of a correct feature. The first type refers to the linguistic features that a learner masters at a particular level and accurately uses them at higher levels. This category contains 'positive linguistic properties' (sentences, constructions, their meanings, etc.), which "are generated by the grammar of the relevant language - here English - and are judged to be well-formed, and used by native speakers" (Hawkins \& Buttery, 2010, p. 4). The second group of linguistic features - developing language features - embraces features that are employed by a learner at a particular level, yet not always consistently or correctly (Salamoura \& Saville, 2010). These features are often referred to as 'negative grammatical features', since they "fall outside the set generated and $[\ldots]$ are judged ill-formed by native speakers" (Hawkins \& Buttery, 
2010, p. 4). The remaining two groups of linguistic features are referred to as acquired/native-like and developing/non-native-like usage distributions of a correct feature. The former puts emphasis on the positive usage of a correct L2 property that matches the distribution of native speaking users, whereas the latter presupposes negative usage distributions of a correct property of L2 that do not match the distribution of native speaking users. As it is seen, the four types of criterial features do not only indicate what FL learners can or cannot do but also what they cannot do in comparison to native speakers. Salamoura and Saville (2010) maintain that all these three aspects and language performance - can do, cannot do, and cannot do to the same extent as native speakers - underlie second language proficiency, which should be investigated to "identify the limits of learners' performance at each CEFR level" (2010, p. 112).

Apart from the description of a set of criterial features describing the grammatical, lexical and functional competence of EFL learners at a particular CEFR level, the EPP also provides a list of typical errors for the six levels of proficiency. Following the principal approach of the CEFR, the EPP identifies generalized features of EFL learners without taking into account their first language and derives its data from the Cambridge Learner Corpus (55.5 million words), representing over 140 first grammatically and typologically different languages (O'Keeffe \& Mark, 2017). Nearly a half of the corpus is coded for errors that are classified into 70 error types involving lexical, syntactic and morpho-syntactic properties of English, which Cambridge University Press coders consider as incorrectly used by non-native speakers.

The study presented here deals with the grammatical complexity of learner language produced by Lithuanian students of English Philology in their last year of BA studies. The English Grammar Profile, which enumerates grammatical criterial features (GCFs) characteristic of each CEFR proficiency level (UCLES/CUP, 2011; Hawkins \& Filipović, 2012), is used as a reference tool for grammatical criterial features.

The present study aims at investigating to what extent the list of grammatical criterial features (GCFs) proposed by the English Profile Programme (EPP) at the University of Cambridge is applicable to students of English Philology at Lithuanian University of Educational Sciences (LEU) in their final year of BA studies. The BA study programme of English Philology at LEU expects its graduates to attain C1 level. Although the EPP primarily draws on the electronic corpus of the data collected from written assignments of EFL school learners across the world, it is assumed that the outlined criteria can be applied for the investigation of university students' 
written assignments, as the EPP covers all the six proficiency levels proposed in the CEFR.

The author of the paper does not wish to extend the obtained results to the national scale, yet strongly believes that the findings might shed light on and reveal major tendencies in the development of foreign language proficiency of English Philology students in Lithuania.

\section{Data and Methods}

The data for the investigation of GCFs employed by English Philology students is derived from a sample of essays. It consists of 35 essays written on different topics throughout the spring semester of the 2016-2017 academic year. The total number of words is 22,819 ; the average essay length is 652 words. The sample represents the essays that received only positive evaluations.

A frequent approach to the investigation of the grammatical proficiency of FL learners involves error analysis (Abe, 2007; Thewissen, 2013). However, this present study focuses on the correct use of GCFs by EFL students.

The study is performed employing the English Grammar Profile (EGP), which is a constituent part of the English Profile Programme. With respect to grammar, the EPP outlines reference level descriptors (RLDs) that embrace grammatical and lexical details with the aim of extending the characteristics of CEFR language proficiency levels (UCLES/CUP, 2011). Hence, the EGP seeks to establish which grammatical features distinguish learners at each level of the CEFR. Differently from other learner corpora (ICLE International Corpus of Learner Language, Granger, 2003; LINDSEI - the Louvain International Database of Spoken English Interlanguage, Gilquin, De Cock \& Granger, 2010; and some others), the EPP, EGP in particular, is the only learner corpus that draws on particular syntactical patterns. Since our research focuses on the respondents that are expected to have attained level $\mathrm{C} 1$, level A2 has been excluded from the investigation as being below the established standard of the current investigation. Consequently, the sample of essays was analysed in terms of the features listed for levels B1 (18 structures), B2 (10 structures), C1 (5 structures) and C2 (3 structures) (UCLES/CUP, 2011, p. 18-24; Hawkins \& Filipović, 2012, p. 147-151). Owing to its small amount, the research data has been processed manually. 


\section{Results and Discussion}

Out of 48 GCFs (grammatical criterial features) included in the English Grammatical Profile, 36 were taken for the investigation (excluding level A). The research data analysis reveals that ten GCFs have not been found at all, whereas eight occur infrequently (less than 10 times in 35 essays). The broadest range of features established in the corpus belong to level B2. C1 features are not so numerous, whereas $\mathrm{C} 2$ features can hardly be attested at all. The research results are discussed in the following four sections, each reporting the findings for levels $\mathrm{B} 1, \mathrm{~B} 2, \mathrm{C} 1$ and $\mathrm{C} 2$.

\section{Level B1 Features}

B1 is detailed by eighteen GCFs in the EPP. More than half of them (B1.1 - B1.5, B1.8 - B1.9, B1.11, B1.15) are defined in terms of general patterns (phrases, clauses) based on a particular word class in UCLES/ CEU (2011). Others refer to specific clauses or narrowly defined patterns (B1.6 and B1.15, respectively), or to specific lexical items (B1.10, B1.12 - B1.14, $\mathrm{B} 1.16-\mathrm{B} 1.18)$.

Table 1. Frequencies of Level B1 Features

\begin{tabular}{|c|l|c|}
\hline Feature & \multicolumn{1}{|c|}{ Description } & $\begin{array}{c}\text { Absolute } \\
\text { frequency }\end{array}$ \\
\hline B1.1 & $\begin{array}{l}\text { Verb + object + infinitive: I called my assistant and ordered him to } \\
\text { gather my men to the hall. }\end{array}$ & 46 \\
\hline B1.2 & Verb + object + Verb ending in -ing: Maria saw him taking a taxi. & 19 \\
\hline B1.3 & $\begin{array}{l}\text { Noun + descriptive phrase introduced by present participle: I was } \\
\text { desperate I put an advertisement in the newspaper asking if } \\
\text { someone had it, but no one answered me. }\end{array}$ & 37 \\
\hline B1.4 & $\begin{array}{l}\text { It + Verb + subordinate clause with/ without that: It's true (that) } \\
\text { I don't need a ring to make me remember you. }\end{array}$ & 9 \\
\hline B1.5 & $\begin{array}{l}\text { Verb + Prepositional Phrase + subordinate clause with/without that: } \\
\text { He said to me (that) he would like to come back soon. }\end{array}$ & 17 \\
\hline B1.6 & $\begin{array}{l}\text { Relative clauses with whose: ... a biography of this famous painter } \\
\text { whose pictures I like so much. }\end{array}$ & 14 \\
\hline B1.7 & $\begin{array}{l}\text { WH-word + NP + Verb clauses used as subject or object: What } \\
\text { I absolutely dislike is to go shopping, although I really like new } \\
\text { clothes. I opened the door and what I saw was so amazing. }\end{array}$ & \\
\hline
\end{tabular}


Table 1 (continued)

\begin{tabular}{|c|l|c|}
\hline Feature & \multicolumn{1}{|c|}{ Description } & $\begin{array}{c}\text { Absolute } \\
\text { frequency }\end{array}$ \\
\hline B1.8 & $\begin{array}{l}\text { Indirect WH-questions: I don't know how I could have done it. } \\
\text { Guess where it is. }\end{array}$ & 15 \\
\hline B1.9 & $\begin{array}{l}\text { Indirect WH-questions with infinitive: I didn't know where to look } \\
\text { for it anymore. }\end{array}$ & 11 \\
\hline B1.10 & $\begin{array}{l}\text { Complex auxiliaries would rather and had better. If you don't like to } \\
\text { go with them you had better tell them why you don't want to come. }\end{array}$ & 0 \\
\hline B1.11 & $\begin{array}{l}\text { Adverbial subordinate clauses with -ing that follow the clause to } \\
\text { which they are attached: He was sitting there, drinking coffee and } \\
\text { writing something. }\end{array}$ & 28 \\
\hline B1.12 & $\begin{array}{l}\text { Seem, supposed + infinitive: Monika seems to be good, intelligent } \\
\text { teacher, but I have a bad feeling about Paula. }\end{array}$ & 2 \\
\hline B1.13 & $\begin{array}{l}\text { expect, like, want + object + infinitive: Sara told me she would } \\
\text { come, but I didn't expect her to come so early. }\end{array}$ & 0 \\
\hline B1.14 & $\begin{array}{l}\text { easy + infinitive: The train station is easy to find. The problem you } \\
\text { have is not very easy to solve.* }\end{array}$ & 2 \\
\hline B1.15 & $\begin{array}{l}\text { Double embedded genitive with (of...(-'s)): I am a big fan of the } \\
\text { world's most famous British secret service agent. }\end{array}$ & 7 \\
\hline B1.16 & $\begin{array}{l}\text { MAY in the Permission (deontic) sense: May I borrow your bicycle } \\
\text { for this weekend? }\end{array}$ & 0 \\
\hline B1.17 & $\begin{array}{l}\text { MUST in the Necessity (epistemic) sense: This movie must be } \\
\text { great. He is having a great time and must be really happy there. }\end{array}$ \\
\hline B1.18 & $\begin{array}{l}\text { SHOULD in the Probability (epistemic) sense: I have invited all my } \\
\text { friends, [so] we should be 28 people. }\end{array}$ & 5 \\
\hline
\end{tabular}

${ }^{*}$ The descriptions and illustrative examples are taken from UCLES / CUP (2011).

** It is assumed that the single adjective 'easy' considerably narrows the pattern; therefore, other adjectives used in the same pattern (adjective + infinitive) have also been ascribed to this pattern.

As it is seen from Table 1, the bulk of GCFs pertaining to level B1 is made of general word-class-based patterns (187 instances out of 227). Features B1.10, B1.13, B1.16 and B1.17 have not been found in the corpus. These features mostly pertain to the narrowly defined patterns, like would rather/had better; or some specific use of the modal verbs may and must.

The most frequent case appears to be the one that could be ascribed to the transferrable features, which are easily calqued from Lithuanian (cf. Juknevičienè \& Šeškauskienė, 2014). For example, a B1.1 structure containing verb + object + infinitive is easily explained by its proximity to the equivalent Lithuanian structure. 
Cf.

It [Anxiety] is the main driving mechanism that helps students achieve their academic goals. (B1.1)

Lith. Nerimas - tai pagrindine varomoji jèga, kuri padeda studentui siekti studiju tikslu.

Moreover, some Lithuanian researchers claim that Lithuanian EFL users tend to overuse the -ing constructions (Grigaliūnienè \& Juknevičiené, 2012; Rimkute, 2006), whereas EFL users from other backgrounds tend to underuse or misuse these constructions (cf. Springer, 2012). Our research also confirms the findings of Lithuanian studies performed by Juknevičienè \& Šeškauskienè (2014) as well as Grigaliūnienè \& Juknevičienė (2012) by revealing that -ing clause structures are another abundantly used GCF (B 1.2, $\mathrm{B} 1.3$; B1.11 and B2.1) at B1 level. It is again accounted for by the frequent use of participial forms in Lithuanian.

Cf.

People are able to achieve their harmonious balance devoting some time to discovering and developing their spiritual side. (B1.11)

Lith. [...] skirdami laiko savo dvasinio pasaulio atradimui ir ugdymui.

Nowadays the phenomenon of employing a modified pronunciation seems to be widespread in music industry involving different genres of music. (B1.3)

Lith. [...] muzikos industrija, apimančia ivairius muzikos žanrus.

Special attention should be paid to adverbial participial -ing clauses. The study performed by Grigaliūnienè \& Juknevičienè (2012) reveals that undergraduate students of English (70\%) tend to place adverbial clauses after the main clause. However, our data show that in terms of the positioning of -ing adverbial subordinate clauses, there is a tendency to use them prepositively (cf. B1.11 - 28 instances and B2.1 - 41 instances).

Cf.

Children often experience harassment by other individuals while using social platforms. (B1.11)

After watching a movie like this, people, especially children, tend to believe that they should also have new Apple phones and computers. (B2.1) 
Another B1 level GCF that is frequently employed by EFL students is B1.7, which is also attributed to general patterns (WH-word $+\mathrm{NP}+\mathrm{Verb}$ ):

What most students try to do is to organise their time they have according to their needs (B1.7).

As it has already been mentioned, four features have not been not discovered in our sample at all, whereas another six features are used infrequently (less than 10 times per sample). In most cases, these are the structures mostly dealing with specific or narrowly defined patterns (B1.10, $\mathrm{B} 1.12$ - B1.14, and B1.14 - B1.18) that are rather uncommon for the Lithuanian language (e.g. B1.6, B1.10 and some others).

\section{Level B2 Features}

There are ten B2 level GCFs identified in the EPP manual (UCLES/CUP, 2011). As presented in Table 2, only one feature out of ten B2 structures was not used by the Lithuanian students of English Philology. Comparing the results obtained for level B1, it is obvious that Lithuanian EFL students are not inclined to employ double embedded genitives in their writing (cf. B1.15, B2.10 and C1.4). Similarly, more general patterns (e.g. B2.1-B2.4) prevail over more specific ones (e.g. B2.7, B2.9-B2.10).

Table 2. Frequencies of Level B2 Features

\begin{tabular}{|c|l|c|}
\hline Feature & \multicolumn{1}{|c|}{ Description } & $\begin{array}{c}\text { Absolute } \\
\text { frequency }\end{array}$ \\
\hline B2.1 & $\begin{array}{l}\text { Adverbial subordinate clauses with -ing that precede the clause } \\
\text { to which they are attached: Talking about spare time, I think we } \\
\text { could go to the Art Museum. }\end{array}$ & 41 \\
\hline B2.2 & $\begin{array}{l}\text { It + Verb + infinite: It would be helpful to work in your group. } \\
\text { B2.3 }\end{array}$ & $\begin{array}{l}\text { WH-word + VP clauses used as subject and object: } \text { What } \\
\text { attracted me the most was the possibility of meeting people } \\
\text { of the same interests. }\end{array}$ \\
\hline B2.4 & $\begin{array}{l}\text { Verb + object + subordinate clause with/without that: I told } \\
\text { him I loved his songs. She told me that she had worked for } \\
\text { summer camp for children. }\end{array}$ & 24 \\
\hline B2.5 & $\begin{array}{l}\text { Verb + object + adjective: But if you don't want to take any risks, } \\
\text { just go and paint the house yellow and blue. }\end{array}$ & 82 \\
\hline
\end{tabular}


Table 2 (continued)

\begin{tabular}{|c|l|c|}
\hline Feature & \multicolumn{1}{|c|}{ Description } & $\begin{array}{c}\text { Absolute } \\
\text { frequency }\end{array}$ \\
\hline B2.6 & $\begin{array}{l}\text { Verbs appear, cease, fail, happen, prove, turn out and } \\
\text { adjectives certain, likely, sure, unlikely + infinitive: To my regret, } \\
\text { the evening totally failed to live up to my expectations. }\end{array}$ & 34 \\
\hline B2.7 & $\begin{array}{l}\text { imagine, prefer + object + infinitive: I would prefer my } \\
\text { accommodation to be in log cabins because I am allergic to } \\
\text { some insects that might go in the tent. }\end{array}$ & 3 \\
\hline B2.8 & $\begin{array}{l}\text { Verbs expected, known, obliged, thought (in Passive voice) + } \\
\text { infinitive: So zoos could be the only place where people could } \\
\text { spend their time avoiding the pollution we are obliged to live } \\
\text { with every day. }\end{array}$ & 27 \\
\hline B2.9 & $\begin{array}{l}\text { difficult, good, hard + infinitive: The grammar and vocabulary } \\
\text { are a bit hard to learn. }\end{array}$ & 3 \\
\hline B2.10 & $\begin{array}{l}\text { Double embedded genitive with ((of...) -'s): After that I went to } \\
\text { a friend of mine's house where / spent one week. }\end{array}$ & 0 \\
\hline
\end{tabular}

As it is seen from Table 2, the most frequent and least problematic feature seems to be B2.2, referring to complex clauses containing one main clause beginning with it and a verb, followed by a subordinate complement clause with an infinitive, for example:

Then, it is recommended to explore other parts of the body $<\ldots>$.

It is always important to stay in touch with old people.

This finding confirms the research results obtained by Juknevičiene \& Šeškauskienè (2014), who explore the essays written for national school examination in English. According to the authors, this structure competes with B1.14, as the former is acquired quite early by Lithuanian learners, whereas the latter is not much paid attention to while learning English at school.

Similarly to B1 structures, -ing participial constructions (B2.1) are rather a common feature in the essays of university students, yet at level B2 they are used in adverbial subordinate clauses with -ing that precede the clause to which they are attached:

Discussing mass communication, the article gives a description of what mass communication is.

Plaving [computer] games for long periods, children sit immovable for a long time, which causes their obesity. 
Being told about the diagnosis, further treatment and its side effects, a patient gains trust in his doctor.

As it has already been discussed, this structure does not cause difficulty for Lithuanian students, as it can be translated verbatim.

Differently from the findings of other Lithuanian researchers (Juknevičienė \& Šeškauskienė, 2014; Grigaliūnienè \& Juknevičienė, 2012), the narrowly defined patterns, such as B2.6 and B2.8, are quite frequently employed by the university students, for instance:

Consequently, adolescents are likely to act, speak and behave in the same way.

Doctors then fail to treat such diseases.

The above mentioned authors claim that students fail to use these patterns due to their narrow lexical definition. Nevertheless, our research proves that these structures are not problematic for students to learn, provided they are encouraged to do so.

Another GCF that is worth paying attention to is B2.3. Similarly to level B1 (B1.7), this feature turns out to be quite a frequent occurrence in the sample:

What may cause a student to fall behind academically is anxiety because anxiety often affects working memory, attention and other abilities (B2.3).

The least frequent structures are those that are very narrowly defined and, therefore, yield few or no instances at all. At level B2, these features refer to B2.7, B2.9 and B2.10. As far as feature B2.7 is concerned, it involves very specific lexical items imagine and prefer. Surprisingly though, feature B2.8 contains the aforesaid and other lexical items in the passive form, which accounts for 27 instances per sample. This discrepancy may have occurred due to the fact that the former feature (B2.7) is more restricted in the number of lexical items than B2.8. Besides, passive constructions are considered to be more characteristic of academic prose (Biber, Conrad \& Leech, 2002). Considering the low frequency of feature B2.9, a parallel can be drawn with B1 level feature B1.14 (easy + infinitive). In this respect, our research confirms the findings of Juknevičienè \& Šeškauskienè (2014), who maintain that the structure adjective + infinitive is difficult for Lithuanian learners to grasp at any level of their FL proficiency. 


\section{Level C1 Features}

Level $\mathrm{C} 1$ grammatical criterial features are described by only five structures in the EPP manual (Table 3). All of them refer to very narrowly defined patterns or specific lexical items. Therefore, out of 5 features that are ascribed to level C1, only 2 are used by the students: C1.2 and C1.3.

Table 3. Frequencies of Level C1 Features

\begin{tabular}{|c|l|c|}
\hline Feature & \multicolumn{1}{|c|}{ Description } & $\begin{array}{c}\text { Absolute } \\
\text { frequency }\end{array}$ \\
\hline C1.1 & $\begin{array}{l}\text { The verb chance + infinitive: I chanced to know about your } \\
\text { competition from an international magazine. }\end{array}$ & 0 \\
\hline C1.2 & $\begin{array}{l}\text { believe, find, suppose, take + object + infinitive: Overall I found } \\
\text { this to be pretty satisfying as it does fulfil most of the students' } \\
\text { wishes. }\end{array}$ & 11 \\
\hline C1.3 & $\begin{array}{l}\text { assumed, discovered, felt, found, proved, etc. (in Passive voice) } \\
\text { + infinitive: The children stories were felt to be the best idea for } \\
\text { kids, after of course the pony rides. }\end{array}$ & 0 \\
\hline C1.4 & $\begin{array}{l}\text { Double embedded genitive with ((-'s) -'s): After spending the first } \\
\text { day of their marriage in the bride's family's house... }\end{array}$ & 0 \\
\hline C1.5 & $\begin{array}{l}\text { Modal MIGHT in the Permission (deontic) sense: Might I tell you } \\
\text { what we discuss? }\end{array}$ & 0 \\
\hline
\end{tabular}

Both of the features refer to narrowly defined patterns containing particular lexical items (C1.2 - specific verbs in the active voice and C1.3 specific verbs in the passive voice), for example:

There is one more key factor that is expected to have a strong influence on our perception of life satisfaction.

Television and the internet are assumed to have disrupted newspaper business.

Local newspapers are supposed to integrate with the Web.

I suppose the impact of social media on teenagers to be very high.

\section{Level C2 Features}

The scarce findings from the $\mathrm{C} 2$ corpus provide no basis for discussion. Only 8 structures were identified in the data on C2 level. It is defined in reference to particular lexical verbs, which are used in the main clause 
and followed by a noun phrase and a subordinate clause with an infinitive verb.

Table 4. Frequencies of Level C2 Features

\begin{tabular}{|c|l|c|}
\hline Feature & \multicolumn{1}{|c|}{ Description } & $\begin{array}{c}\text { Absolute } \\
\text { frequency }\end{array}$ \\
\hline C2.1 & $\begin{array}{l}\text { declare, presume, remember + object + infinitive: They declare } \\
\text { some products to be the hits of the season. }\end{array}$ & 6 \\
\hline C3.2 & $\begin{array}{l}\text { The verb presumed (in Passive voice) + infinitive: Not only } \\
\text { meetings with people are presumed to give new experiences. }\end{array}$ & 2 \\
\hline C2.3 & $\begin{array}{l}\text { tough + infinitive: What she knew would be really tough to live } \\
\text { with was the reason of his death. }\end{array}$ & 0 \\
\hline
\end{tabular}

The meagre findings of the $\mathrm{C}$ level grammatical criterial features presumably indicate that the structures characterising this level have not been attained by the student during their studies. Another argument is concerned with the fact that level $\mathrm{C}$ is described more tenuously in comparison to levels $\mathrm{A}$ and $\mathrm{B}$, which might have led to inconsistent findings of our research.

\section{Conclusions}

The study has provided a comprehensive picture of grammatical range in the written language of students of English Philology at Lithuanian University of Educational Sciences in their final year of studies. The English Profile Programme (UCLES/CUP, 2011) provides a solid basis for the investigation of grammatical criterial features, characterising the level of EFL students' grammar proficiency in the language.

First, although the BA study programme of English Philology at LEU expects its graduates to attain $\mathrm{C} 1$ level, the study proves that the level of the English Philology students is ascribed to B2 level in terms of the compliance with GCFs outlined in the EPP ${ }^{1}$. Similarly to the findings of other Lithuanian authors (Juknevičienè \& Šeškauskienè, 2014; Grigaliūnienė \& Juknevičienė, 2012), the findings of the current study suggest that Lithuanian students of English Philology make do with a restricted repertoire of grammatical

\footnotetext{
Despite the fact that the number of instances seems to be larger at level B1, the author of the current study, bearing in mind that the number of features characteristic of both levels is unequal (B1 is described in nearly twice as many features as B2), assumes that the level of students' proficiency can be ascribed to level B2 of CEFR.
} 
structures. This is a fact that both University teachers and Programme developers should take into consideration.

Second, Lithuanian students of English Philology tend to use the structures that are identical or easily comparable to their mother tongue. These GCFs mostly include clausal structures: B1.1, B1.3, B1.11, B2.1, B2.2 and B2.4. Differently from other studies referred to in the paper, our research reveals that the BA students of English Philology also employ narrower structures containing specific lexical items (B2.6, B2.8, C1.2 and C1.3), which might be ascribed to their higher level of EFL proficiency.

However, when carrying out our investigation, certain limitations have been encountered. First, a small number of the respondents prevented us from yielding more exhaustive research findings that would be representative on the national scale. Second, the unequal number of criterial features characterising each CEFR level might have caused justifiable violations in the research results. It is assumed that describing the features by approximately the same number of characteristics would be beneficial to drawing more consistent conclusions. Moreover, unequal degree of the generality of GCFs describing each CEFR level (some of them referring to rather broadly defined patterns and others to highly limited and specific lexical items) might also have prevented us from drawing comparable results for each CEFR level under analysis. Finally, a rather varied description of the characteristic features might misrepresent the CEFR levels and prevent learners from striving to acquire more complicated structures in the course of developing their EFL proficiency. Therefore, one of the ways to encourage the use of more complex structures would be to develop a clear system of criteria for each of the levels tested in each year of studies so that both teachers and students would have a clear picture of lexico-grammatical range and complexity.

\section{References}

Abe, M. (2007). "Grammatical Errors Across Proficiency Levels in L2 Spoken and Written English." The Economic Journal of Takasaki City University of Economics, No. 49 (3-4), 117-129.

Biber, D., Conrad, S., \& Leech, G. (2002). Student Grammar of Spoken and Written English. Harlow: Pearson Education Ltd.

Biber, D. \& Reppen, R. (1998). "Comparing native and learner perspectives on English grammar: a study of complement clauses." In S. Granger (Ed.), Learner English on Computer. London, New York: Longman, 145-158. 
Callies, M. \& Zaytseva, E. (2013). “The Corpus of Academic Learner English (CALE): a new resource for the study and assessment of advanced language proficiency." In S. Granger, G. Gilquin and F. Meunier (Eds.), Twenty Years of Learner Corpus Research: Looking back, Moving ahead. Corpora and Language in Use - Proceedings 1. Louvain-la-Neuve: Presses Universitaires de Leuvain, 49-59.

Council of Europe (2018). Common European Framework of Reference for Languages: Learning, Teaching, Assessment. Companion Volume with New Descriptors. Retrieved from: https://rm.coe.int/cefr-companion-volume-withnew-descriptors-2018/1680787989.

Gilquin, G., De Cock, S. \& Granger, S. (2010). LINDSEI: Louvain International Database of Spoken English Interlanguage. Louvain-la-Neuve: Presses Universitaires de Leuvain.

Granger, S. (2002). "A bird's-eye view of learner corpus research.” In S. Granger, J. Huang \& S. Petch-Tyson (eds.). Computer Learner Corpora, Second Language Acquisition and Foreign Language Teaching. Amsterdam: John Benjamins, 3-33.

Granger, S. (2003). International Corpus of Learner English: a new resource for foreign language learning and teaching and second language acquisition research. TESOL Quarterly, 37(3), 538-546.

Grigaliūnienè, J. \& Juknevičienè, R. (2012). "Corpus-based learner language research: contrasting speech and writing." Darbai ir dienos, 58, 137-152.

Hawkins, J. A. \& Buttery, P. (2010). “Criterial features in learner corpora: theory and illustrations." English Profile Journal, 1 (1), 1-23. DOI: 10.1017/ S2041536210000103.

Hawkins, J. A. \& Filipovic, L. (2012). Criterial Features in L2 English: Specifying the Reference Levels of the Common European Framework. Cambridge: Cambridge University Press.

Hulstijn, J. H. (2014). "The Common European Framework of Reference for Languages: a challenge for applied linguistics." International Journal of Applied Linguistics, 165 (1), 3-18. DOI: 10.1075/itl.165.1.01hul.

Juknevičienè, R. \& Šeškauskienè, I. (2014). "The national examination of English in Lithuania: searching for evidence of CEFR criterial achievement levels." Studies About Languages, 25, 88-96. DOI: 10.5755/j01.sal.0.25.8579.

Milanovic, M. (2009). "Cambridge ESOL and the CEFR." University of Cambridge ESOL Examinations Research Notes, 37, 2-5.

O'Keeffe, A. \& Mark, G. (2017). "The English Grammar Profile of learner competence: methodology and key findings." International Journal of Corpus Linguistics, 22 (4), 457-489. DOI: 10.1075/ijcl.14086.oke.

Rimkute, E. (2006). "The usage of grammatical forms of contemporary Lithuanian language in the morphologically annotated corpus." Lituanistika, 66 (2), 34-55 .

Salamoura, A. \& Saville, N. (2010). "Exemplifying the CEFR: criterial features of written learner English from the English Profile Programme.” In I. Bartning, 
M. Martin and I Vedder (eds). Communicative Proficiency and Linguistic Development: Intersections between SLA and Language Testing Research. European Second Language Association (Eurosla). Retrieved from: http:// eurosla.org/monographs/EM01/101-132Salamoura_Saville.pdf.

Springer, P. E. (2012). "Advanced Learner Writing. A Corpus-based Study of the Discourse Competence of Dutch Writers of English in the Light of the C1/C2 Levels of the CEFR (doctoral dissertation)." Uitgeverij: Boxpress Oisterwijk. Retrieved from: https://research.vu.nl/ws/portalfiles/portal/42108832/ complete\%20dissertation.pdf.

Thewissen, J. (2013). "Capturing L2 Accuracy Developmental Patterns: Insights from an Error-tagged EFL Learner Corpus." The Modern Language Journal, 97 (S1), 77-101.

UCLES/CUP (2011). English Profile. Introducing the CEFR for English (version 1.1). Cambridge: Cambridge University Press. Retrieved from: http://www. englishprofile.org/images/pdf/theenglishprofilebooklet.pdf. 